\title{
Globalization and Health in Kosovo
}

\author{
Albina Balidemaj \\ Clemson University, USA \\ Barre Hall, Clemson, South Carolina, 29634-0132 abalide@g.clemson.edu \\ Festina Balidemaj \\ Oxford University, UK \\ Square, Oxford OX1 2JD, United Kingdom festina.balidemaj@gmail.com
}

\begin{abstract}
Kosovo and the region have had a traditionally long history of problems with the health care system. The situation worsened since the ex-Yugoslav conflict in the nineties when Kosovo inherited a large, hierarchical, and centralized healthcare system from socialist Yugoslavia (UNDP, 2013). This paper focuses on the effects of globalization on health in Kosovo; more specifically the effect of Global Food Trade in Kosovo's health and the development of information technology and telemedicine in Kosovo. Further, this paper focuses on the opportunities for Kosovars to obtain healthcare outside of Kosovo as well as prospects for the medical personnel to practice their profession abroad.
\end{abstract}

Keywords: Globalization, healthcare, Kosovo

\section{Globalization and Health: The Case of Kosovo}

Economics studies have addressed the consequences of globalization on health, yet the lone terminology of health seems to be mostly absent in the literature of globalization and economics. Subsequently, literature shows many definitions for the term 'globalization'. Globalization is best defined by Lee (2003) in terms of three types of changes which have been occurring at unparalleled rates over the past few decades: Spatial changes (movement of people), Temporal changes (perception of time and experience), and Cognitive changes (perception of self and world).

Most of the existing literature, however, describes the effect of globalization on health as either "good" or "bad" (Lee, 2003; Frenk \& Gomez-Dante, 2002) and generally, the literature in the health sciences takes a more negative view of globalization (Frenk \& Gomez-Dante, 2002). According to the American Institute of Medicine (2007), the perceived threat of health from globalization is mainly focused on the potential movement of people from low- and middle- income countries. Rich countries, on the other hand, fear the potential financial burden of unhealthy populations migrating from the developing world (American Institute of Medicine, 2007). Most of the rich countries tend to overlook the migration of health professionals from poorer countries, who benefit the health system in their countries (Collin, 2003). Additionally, the privatization of health services is seen in literature as a threat to the health of the poor, who are typically served by public provision (Drèze and Sen, 2002). Moreover, concerns about mutual trade agreements between the US and other countries, especially when the interests of the US pharmaceutical companies are at stake, are strongly noted throughout literature (Frenk \& Gomez-Dante, 2002).

Moreover, food companies are also seen as a threat on global heath, noting that Africa is now the only continent in which the majority of deaths are from infectious diseases, rather from heart disease and cancer (World Health Organization, 2010). World Health also notes that the majority of the developed and developing countries now suffer from the 'epidemic' of obesity. On the contrary, Bordo et al. (2003) write that higher income promotes better health. In support, Preston (1980) notes that the link between income and health is typically strong in poor countries suggesting that the reduction of poverty globally would improve population health.

Generally, the effects of globalization on health are both positive and negative. The equilibrium between these two effects is country and population specific (Lee, 2003). Moreover, the effects are also dependent on one's geographical location, sex, age, ethnic origin and educational level (Deaton, 2004). The challenge with the effects of globalization emerges when trying to unravel individual impacts on health and their specific distributions across populations. Population health is also affected by the global changes in economy, environment and population movement (Deaton, 2004). One of 
the key challenges of the modern world is the management of globalization, as globalization does not have a fixed course but follows the path that favors certain interests and avoids others (Syed et al., 2012).

Globalization has affected Kosovo in many areas positively and negatively. In Kosovo, the health sector has suffered from not only the physical destruction of violent conflict but from long-term under-investment in staff development and lack of maintenance of physical infrastructure and equipment (United Nations, 2005). Kosovo's health budget is highly supported by donor funding (UN, 2005; WHO, 2010).

This paper focuses on the effects of globalization on health in Kosovo; more specifically the effect of Global Food Trade in Kosovo's health and the development of information technology and telemedicine in Kosovo. Further, this paper focuses on the opportunities for Kosovars to obtain healthcare outside of Kosovo as well as prospects for the medical personnel to practice their profession abroad.

\section{Background: Kosovo Health System}

Kosovo and the region have had a traditionally long history of problems with the health care system. The situation worsened since the ex-Yugoslav conflict in the nineties when Kosovo inherited a large, hierarchical, and centralized healthcare system from socialist Yugoslavia (UNDP, 2013).

The health system in Kosovo, as elsewhere in Eastern Europe, was largely based on the Semashko model of healthcare delivery. The Semashko system of health care was utilized throughout the Soviet Union and Eastern Europe and it centralized decision-making by emphasized specialization of services through a doctor-, hospital- and treatmentoriented system (UNDP, 2013). The first points of contact for patients were the polyclinics, which were located in major towns and municipalities. The central government functioned as the purchaser and provider of the health care services (Ministry of Health, 2013).

Under the 1974 Yugoslav Constitution, Kosovo had been granted autonomous status within the Republic of Serbia. This status was revoked by Belgrade in March 1989, initiating a decade of tension and conflict. The health sector became a natural battleground for the conflict between Kosovo's majority Albanian population and the federal government in Belgrade. Over $90 \%$ of clinics and health institutions were damaged during the war, and many private clinics of Albanian health professionals were destroyed. A general collapse of the public-service infrastructure, particularly water and electricity, deeply affected the health sector (Buwa \& Vuori, 2006). The Serbian Ministry of Health assumed control of the Kosovo health system, and directors and boards of health institutions were forced to report directly to Belgrade.

Discrimination of Kosovar patients and doctors by Serb-dominated medical staff was one of the main problems followed by the lack of practical and professional experience of the medical staff. Needless to say, after decades of no investment, maintenance or renovations, the infrastructure became outdated and deeply consumed (Holst, 2007). The frequency rate of infectious diseases rose; immunization rates declined, and vaccination coverage for children against polio, diphtheria, tetanus, etc., fell below 60 percent, with some areas falling below 30 percent coverage (Ministry of Health, 2013).

Institutions of healthcare in rural areas suffered from lack of personnel and equipment. Access to emergency and after-hours care varied and was unreliable. These services were mostly available only in larger cities and the availability of services through private practices increased dramatically (Percival \& Sondorp, 2010).

At the end of the conflict in 1999, more than 400 donors and aid agencies came to Kosovo, and one of the main tasks was to reconstruct the war-damaged healthcare system (Buwa \& Vuori, 2006). At first, a post-war health reform program was acclaimed as a success; however, the implementation of the reform itself proved to be more problematic than its creation, and as a result, the reform did not accomplish its expected outcomes (Percival \& Sondorp, 2010).

\section{The effect of Globalization in Kosovo Healthcare}

After the end of the conflict, the Ministry of Health was established within the Temporary Government to lead the health sector (UN, 2010). The Ministry defined their priorities of reconstruction by renovating medical facilities, training medical staff, adding cost to medical services and development of health insurance plans (UN, 2010). Thirteen years later, we see both the positive and negative effects of globalization in Kosovo's healthcare. 


\section{Global Food and Tobacco Trade and Health in Kosovo}

One of the factors, which has affected the healthcare worldwide, has been the domination of global food companies and their aggressive marketing strategies to increase the food trade (Chopra et al, 2002). Fat and calorie rich, brand name foods have been contributing to the global epidemic of obesity.

After the war ended in 1999 and especially after Kosovo gained its independence in 2008, many international food brands joined the market. Just in the last decade, Kosovo has started to experience a boom in the fast food industry with zero awareness on the negative effects (Domac, 2011). As a result, the numbers of people who are obese has increased. Consequently, the number of heart disease and cancer is on the raise (Center for Global Research, 2009).

Moreover, the import of tobacco and alcohol in Kosovo has had a negative effect on the overall health. The World Health Organization (WHO) estimates that the death toll from tobacco abuse alone will reach 10 million a year over the next two decades. Up to 70\% of these deaths, caused by lung cancer, cardiovascular diseases (CVDs), lung diseases, diabetes and many other tobacco-related ailments, will occur in developing countries (Murray \& Lopez, 1997). In turn, however, Kosovo has adapted a strong and comprehensive tobacco control law in line with the WHO Framework Convention on Tobacco Control (WHO, 2012).

\section{Information Technology and Telemedicine}

The greatest changes that have taken place during the past 13 years in terms of health have come through the globalization of ideas and information, facilitated through the revolution in information technology worldwide.

The globalization of trade is particularly relevant for health services that have become a commodity to be traded in distinct ways (Crocco et al, 2002). Now, health services can be provided across borders. Examples include a range of telemedicine tools, such as tele-diagnostics and tele-radiology as well as medical consultation through traditional and electronic channels.

In Kosovo, the International Virtual e-Hospital (IVeH), supported by the United States Department of State, Bureau of Educational and Cultural Affairs, implemented the Balkan Telemedicine Program in 2000. This program has created a powerful international medical education network in the Balkans for further collaboration and development as well as a solid foundation for new changes of healthcare in the Balkans.

\section{Obtaining health care abroad}

Other benefits of globalization on health include cross-border use of health services that benefit patients and provide much needed resources to national health systems (Jain, 2003). Increasing numbers of individuals worldwide are leaving their local communities and crossing national borders in search of affordable, timely medical care (Turner, 2010).

Currently, Kosovars spend over $€ 80$ million euros per year on health care abroad (Balkan Policy Institute, 2012) as the healthcare system in Kosovo is still undergoing a reform. In the past, only the wealthy could afford to get treatment abroad, however, the global market place for health care has changed. The Kosovo Government has allocated two million euros for a program, which helps patients to get special treatments abroad that are not available in the country (Ministry of Health, 2013). According to the Ministry of Health, in the first quarter of this year, 287 patients have applied to travel abroad for treatment. The Ministry of Health has made an agreement with the Ministry of the Republic of Turkey, where 42 patients will be treated for free annually (Ministry of Health, 2013).

\section{Health Personnel Brain drain}

The migration of health personnel raises a complex ethical dilemma. Brain-drain of health professionals from the developing to developed countries is well documented (Vijay 2009). As borders disappear, there is an urgent need to develop strategies, at the national and international level, that will minimize the harm and maximize the benefits of the movement of health personnel.

There is surprisingly little data on the scale of the movement of health professionals between poor and rich countries, and few studies have examined the impact of brain drain on national health systems. In the past two years, a large number of young medical doctors from Kosovo have been offered jobs in Germany and Switzerland as these countries 
were recruiting young professionals in several fields from the Balkans. Over 12,000 young professionals have left the country in the past year (Balkan Insight, 2013).

The Ministry of Education and the Government of Kosovo have launched a national "brain-gain" campaign aiming to encourage members of the diaspora and professionals from other countries to take part in the country's development. The main reason for lunching the "brain-gain" program is to create the necessary incentives and mechanisms for stopping and reversing Kosovo's "brain-drain" (Ministry of Education, 2013). The Government is determined to encourage highly educated professionals from Kosovo and abroad to get involved in the process of state building in Kosovo.

\section{Conclusion}

The links between globalization and health are complex and globalization is a complex phenomenon that can affect health in multitude ways. Its consequences can be either direct, at the level of whole populations, individuals and healthcare delivery systems, or indirect, through the economy and other factors, such as education, sanitation and water supply (Woodward et al, 2001).

Without doubt, globalization poses risks to global health, but it also provides benefits. The extraordinary improvements in information technology have dramatically increased the speed and ease of data flow, thereby facilitating the sharing of information. Medical discoveries made in one country can be made nearly instantaneously available to patients in other countries (Wassenaar, 2003).

In Kosovo, the health sector has suffered from not only the physical destruction of violent conflict but from longterm under-investment in staff development and lack of maintenance of physical infrastructure and equipment (United Nations, 2005). Thirteen years after the establishment of the Interim Ministry of Health, we see both the positive and negative effects of globalization in Kosovo's healthcare.

The domination of food and tobacco trade industries in the county has affected the population negatively by creating various diseases including obesity and cancer (Center for Global Research, 2010). However, information technology has affected the health sector in Kosovo very positively by launching a program in telemedicine among others. This program has created a powerful international medical education network in the Balkans for further collaboration and development as well as a solid foundation for new changes in healthcare in the Balkans.

Moreover, globalization had enabled Kosovar citizens' easier access to health care abroad. According to the Ministry of Health, in the first quarter of this year, 287 patients have applied to travel abroad for treatment of Government funds. In return, the Kosovo Government has allocated two million euros for a program, which helps patients to get special treatments abroad that are not available in the country (Ministry of Health, 2013).

Furthermore, over 12,000 young medical professionals have left the country in the past year by being employed abroad (Balkan Insight, 2013). This shows that globalization has affected Kosovo's health system negatively through professional brain drain. The Ministry of Education and the Government of Kosovo have launched a national "brain-gain" campaign aiming to encourage members of the Diaspora and professionals from other countries to take part in the country's development.

In order for Kosovo to keep a stable and improving healthcare system during the global transition, Kosovo needs to have an ongoing healthcare system reform. In addition, the Ministry of Education and the Government of Kosovo need to ensure that the organization of doctoral studies meets the European standards and experience. Moreover, the mobility of research staff needs to be enhanced. It is really important for healthcare professionals to apply their skills attained abroad in Kosovo.

Furthermore, Kosovo needs to make its healthcare data available globally through information and communication technology. A lot of data is currently missing. Factors like data exchange could lead to international medical collaboration. An immediate suggestion on improvement and extension of healthcare developments would be for Kosovo to enhance the collaboration and strengthen capacities with neighboring countries in order to optimize use of limited resources.

In Kosovo, the health sector has suffered not only from the physical destruction of violent conflict but also from long-term under-investment in staff development and lack of maintenance of physical infrastructure and equipment (United Nations, 2005). Nevertheless, the process of globalization has brought very positive factors into Kosovo's healthcare system. 


\section{References:}

[1] Balkan Insight. (2013). Youth Emigration Causing Balkan 'Brain Drain'. Accessed November 25, 2013 from

[2] http://www.balkaninsight.com/en/article/young-people-leave- serbia-bosnia-the-most

[3] Balkan Policy Insitute. (2012). Investigation into public health care in Kosovo. Accessed November 25, 2013 from

[4] http://policyinstitute.eu/images/uploads/InvestigationintoPublicHealthCareinKosovo.pdf

[5] Bordo et al. (2003). Globalization in Historical Perspective. Chicago: University Of Chicago Press.

[6] Buwa, D., \& Vuori, H. (2006). Rebuilding a health care system: War, reconstruction and health care reforms in Kosovo. European Journal of Public Health. 17(2), 226-230.

[7] Center for Global Research. (2009). Fallout of Serbia Bombing 'Continues to Kill'. Accessed November 25, 2013 from http://www.globalresearch.ca/fallout-of-serbia-bombing-continues-to-kill

[8] Collin, J. and Lee, K. (2003). Globalization and Transborder Health Risk in the EU. Case Studies in Tobacco Control and Population Mobility. London. The Nuffield Trust. Accessed November 25, 2013 from

[9]

http://www.sps.ed.ac.uk/_data/assets/pdf_file/0004/96340/2003_Collin_Lee_Globalisation_and_Transborder. pdf

[10] Chopra M., Galbraith S., and Darnton-Hill, I. (2002) A global response to a global problem: the epidemic of over nutrition. Bull WHO. 80: 952-958.

[11] Crocco A., Villasis-Keever M., and Jadad, A. (2002). Two wrongs don't make a right: harm aggravated by inaccurate information on the internet. Pediatrics. 109: 522-523.

[12] Deaton, A. (2004). Health in an age of globalization. Research Program in Development Studies Center for Health and Wellbeing. New Jersey. Princeton University Press.

[13] Domac, J. (2011). California Gives Hope to Kosovo in Fighting the Obesity Epidemic: New Food in a New Nation. Accessed November 30, 2013 from http://nojunkfood.org/?p=204

[14] Frenk, J. \& Gomez-Dantes ,O. (2002) Globalization and the challenges to health systems. Health Aff 21: 160 165.

[15] Holst, J. (2007). The Politics and Economics of Globalization and Social Change in Radical Adult Education: A Critical Review of Recent Literature. Journal for Critical Education Policy Studies. Vol.5 No.1.

[16] Institute of Medicine. (2001). The Impact of Globalization on Infectious Disease Emergence and Control: Exploring the Consequences and Opportunities: Workshop Summary. Accessed November 27, 2013 from http://www.ncbi.nlm.nih.gov/books/NBK56583/

[17] Jain, S.C. (2003) Globalization of medical services: antidote for rising costs. Healthc Pap. 2003;4(2):39-44; discussion 76-81.

[18] Jean, D. and Amartya K. (2002). Development and participation. New Delhi. Oxford University Press.

[19] Lee, J. (2003). Address to the Fifty-third session of the WHO Regional Committee for Africa, accessed November 29, 2013 from http://www.who.int/dg/lee/speeches/2003/johannesburg/en/

[20] Ministry of Health. (2013). Innovation, Information Society, Social and Health Policies. Prishtina: Kosovo Government Printing Office. Accessed November 25, 2013 from

[21] http://www.mei-ks.net/repository/docs/Discussion_Material_Health_Policy.pdf

[22] Murray C.J., Lopez A.D. (1997). Mortality by cause for eight regions of the world: Global Burden of Disease Study. Lancet; 349: 1269-1276

[23] Percival, V., \& Sondorp, E. (2010). A case study of health sector reform in Kosovo. Conflict and Health. 4(7), $1-14$. 
[24] Preston, S.H. (1980). Causes and consequences of mortality declines in less developed countries during the twentieth century. Chicago and London. University of Chicago Press, 289-360.

[25] Syed, S. (2012). Developed-developing country partnerships: Benefits to developed countries? Globalization and Health. 2012, 8:17.

[26] Turner, L. (2010). Quality in health care and globalization of health services: accreditation and regulatory oversight of medical tourism companies. International Journal for Quality in Health Care. Accessed November 25, 2013 fromhttp://www.ahc.umn.edu/bioethics/prod/groups/ahc/@pub/@ahc/@bioethics/d ocuments/content/ahc_content_311818.pdf

[27] United Nations Development Programme. (2005). Human Development Report International Cooperation at a Crossroads: Aid, Trade, and Security in an Unequal World. Human Development Report. New York.

[28] UNDP. (2013). Satisfaction with Healthcare Services and Perceptions on Presence of Corruption. Accessed November 29, 2013 from http://www.undp.org/content/dam/kosovo/docs/publicpulse/DokumentiPerVeprim_Anglisht.pdf

[29] Vijay, N.M. (2009). Medical tourism: Subsidizing health care for developed countries. Accessed November 25, 2013 from http://www.scribd.com/doc/11724381/Medical-Tourism-KABANI1

[30] Wassenaar W (2003) Providing services globally: the experience of an internet pharmacy. Healthc Pap, 4: 6974

[31] WHO (World Health Organization) (2002): Health and the International Economy, Washington, D.C.

[32] Woodward, D., et al. (2001). Globalization and health: a framework for analysis and action. Bull WHO 79: 875-881.

[33] World Health Organization (2010). Confronting the epidemic: a global agenda for tobacco control research. Tobacco Free Initiative. Geneva: WHO, 1999. Accessed November whqlibdoc.who.int/hq/1999/WHO_NCD_TFI_99.12.pdf 